\title{
PARADIGM OF REHABILITATION OF PEOPLE WITH DISABILITY
}

\author{
Aleksandras Kriščiūnas \\ Lithuanian Sports University
}

\begin{abstract}
Background. Disability is part of human condition. The number of people with disabilities is growing. Every epoch has faced the moral and political issue of how to include and support people with disabilities best. This issue will become more acute as the demographics of societies change and more people live to an old age. There is a global increase in chronic health conditions such as diabetes, cardiovascular diseases and mental disorders, which will influence the nature and prevalence of disability. Establishment of a complex rehabilitation system of disabled people is a great challenge.

The aim of this article is to discuss issues concerning the provision of help for people with disabilities and devising effective rehabilitation system for them.

Discussion. Help for people with disabilities should be understood as a versatile system of legal, medical, economical, organizational, etc., means, which help people regain their disturbed biopsychosocial functions, compensate them and adapt them to society. The article further calls to organise, strengthen, and extend comprehensive rehabilitation services and programmes for disabled people and start them as early as possible based on multidisciplinary assessment of individual needs and strengths, including the provision of assistive devices and technologies using ICF.

Conclusion. Multidisciplinary teams can convey many rehabilitation benefits to patients. International cooperation can help share good and promising practices and provide technical assistance to countries that are introducing and expanding rehabilitation services.
\end{abstract}

Keywords: rehabilitation, persons with disabilities, biopsychosocial function, the ICF.

\section{INTRODUCTION}

Disability is part of human condition. The number of people with disabilities has been growing recently (WHO, 2011). Every epoch has faced the moral and political issue of how to include and support people with disabilities best. This issue will become more acute as the demographics of societies change and more people live to an old age. There is a global increase in chronic health conditions such as diabetes, cardiovascular diseases and mental disorders, which will influence the nature and prevalence of disability (Kriščiūnas, Kowalski, 2011). Across the world, people with disabilities have poorer health outcomes, lower education achievements, less economic participation and higher rates of poverty than people without disabilities (WHO, 2011). This is partly because people with disabilities experience barriers in accessing services that many of us have long taken for granted, including health, education, employment, and transport as well as information. These difficulties are exacerbated in less advantaged communities. For some people with disabilities, rehabilitation is essential to being able to participate in education, labour market, and civic life. Rehabilitation is always voluntary, and 
some individuals may require support with decision-making about rehabilitation choices. In all cases rehabilitation should help empower a person with a disability and his or her family (WHO, 2008).

The aim of this article is to discuss issues concerning the provision of help for people with disabilities and devising effective rehabilitation system for them.

\section{DISCUSSION}

Establishment of a complex rehabilitation system for disabled people is a great challenge (Chamberlain, 2015). It should be understood as a versatile system of legal, medical, economical, organizational, etc. means, which helps people to regain their disturbed biopsychosocial functions, compensate them and adapt them to society. The process should be based on the analysis of the current situation, consider the main aspects of rehabilitation provision - leadership, financing, information, service delivery, products and technologies, and the rehabilitation workforce - and define priorities based on the local needs (WHO, 2014).

Principles of rehabilitation organization. Full value of the rehabilitative process is ensured by the maintenance of the aggregate of the main principles which are formulated as follows: availability, timeliness, individualization, completeness, adequacy, periodicity, succession and continuity, informatively, and modular approach.

Rehabilitation involves identification of a person's problems and needs, relating the problems to relevant factors of the person and the environment, defining rehabilitation goals, planning and implementing the measures, and assessing the effects. Rehabilitation measures contribute to a person achieving and maintaining optimal functioning in the interaction with their environment, using the following broad outcomes:

- Prevention of the loss of function,

- Slowing the rate of the loss of function,

- Improvement or restoration of function,

- Compensation for lost function,

- Maintenance of current function.

The WHO, consisting of 193 countries, suggested the introduction of a biopsychosocial health care model. According to this model, when assistance is delivered to patients, assessment involves not only the causes of health disorders, but it also concerns the outcomes that can be reduced through environmental adjustment for the patient, application of technical rehabilitation means and the influence to the patient's behaviour. With that purpose in mind, The International Classification of Functioning, Disability and Health was developed by the WHO. 
Implementation of the International Classification of Functioning, Disability and Health (ICF) in rehabilitation is very important (WHO, 2001; WHO, 2007).

The classification aims to:

- provide a scientific basis for understanding and studying health and healthrelated conditions, outcomes and determinants;

- establish a common language for describing health and health-related conditions in order to improve

- communication between different users, such as health care workers, researchers, policy-makers and the public, including people with disabilities;

- enable comparison of data across countries, health care disciplines, services and time;

- provide a systematic coding scheme for health information systems.

This classification emphasizes the individuality of the sick person and the environment, and highlights not only the symptoms of the disease, but also the disturbed activities and social capabilities of the person. ICF problems with human functioning are categorized in three interconnected areas:

- impairments: problems in body function or alterations in body structure;

- activity limitations: difficulties in executing activities;

- participation restrictions: problems with involvement in any area of life.

Disability refers to difficulties encountered in any or all three areas of functioning. The ICF can also be used to understand and measure the positive aspects of functioning such as body functions, activities, participation and environmental facilitation. Disability arises from the interaction of health conditions with contextual factors - environmental and personal factors. Environmental factors include: products and technology; the natural and built environment; support and relationships; attitudes; and services, systems, and policies. The ICF also recognizes personal factors, such as motivation and self-esteem, which can influence how much a person participates in society. ICF should be used for functional status assessment, goal setting and treatment planning and monitoring, as well as outcome measurement.

Modular approach to rehabilitation programs. Module (lat. modulus-measure) - is an important part of the system (program) ensuring realization of the whole system (program). Modular program consists of clearly marked parts, which may be changed, supplemented or removed without destruction of the program as a whole and setting up new variations. Modular approach is required to create and to put modules together in a logical way.

Fundamentals of the modular program conception:

- systemic approach;

- paced arrangement and realization of the programs; 
- flexible structure of the program;

- specificity of the individual purposes, programs and evaluation of the fulfilment of their realization.

Main modules of modular program:

- module evaluation of functional state of patients,

- module of nursing,

- module of medication,

- module of kinesiotherapy (physio therapy),

- module of occupational therapy,

- module of psychotherapy,

- module of speech-language therapy,

- module of using assistive devices/technology,

- module of physiotherapy,

- module of teaching patients and family members,

- module of alternative and complementary treatment,

- other (nutrition, vocational, driving).

There is a strong need to develop a modern rehabilitation system for the disabled people in Lithuania. Such system requires holistic approach and a high level of coordination and collaboration from all actors in the system.

Structure of the rehabilitation system includes:

Legal part: Legal acts regulating the work of the system. The Law on Social Integration of the Disabled of the Republic of Lithuania and National Programme of the Integration of the Disabled into the Society for 2013-2019 were passed.

Medical rehabilitation should be developed in the in-patient, out-patient institutions, sanatorium (rehabilitation department), and home facilities (community based rehabilitation). Much has been done in this field. Unfortunately, not all patients in need of medical rehabilitation are able to access it yet. A homebased rehabilitation system for disabled people in Lithuania is still lacking.

Vocational rehabilitation. Vocational rehabilitation centres can provide vocational rehabilitation services (aiming at retrieving lost working skills by restoring, exercising and training) for people with disability. Present vocational rehabilitation centres in Lithuania can provide vocational rehabilitation services for only few of the disabled. In comparison with the average of the European Union countries, the employment rate of the disabled in Lithuania is 2-3 times lower.

Education (training). Participation in significant activities adequate to their status of health, positively influences health condition of people with disability, improves their self-esteem and allows them to integrate into society. Their specific needs are determined not only by nature of disability, but also by their social group 
(i.e. children, the elderly, women, socially supported individuals. The patients' health literacy investigation has revealed that large number of Lithuanian inhabitants do not know opportunities of rehabilitation. Training and education (abilitation) of children is an important part of the rehabilitation system.

Technical rehabilitation aids. About $40 \%$ of the inhabitants in the developed countries use technical rehabilitation aids (not to mention spectacles used by nearly $100 \%$ of the elderly people) in comparison to only $17 \%$ of the Lithuanian population. It is necessary to increase the use of both, individual technical rehabilitation aids (for personal care, mobility) and public technical rehabilitation means and aids (special transportation, supports, props, rails and other equipment for individuals with mobility difficulties, special telephones, sound and light alarm systems). The use of technical rehabilitation aids in Lithuania is limited by their shortage (especially of high-tech equipment), plain appearance, size, weight, short-time fitness, increased breakability, lack of the repair service for fixing of the broken items and people's lack of motivation

Environment adjustment. This is especially important for elderly people at risk of falling and tumbling because of disturbed cerebral circulation. Prevention involves proper street lighting, floor coating, elimination of stairs, adjusted bathroom and toilet equipment, etc.

Recreation. Recreation of the disabled, i.e. recovery of strength, health, joy of life, is an important part of the rehabilitation system. It liberates a person from stigmatization and induces his/her creativity. This can be achieved via cultural events, sport, and religion. The work of governmental and non-governmental organizations is especially important in this field. Inability of spending free time usefully and ensuing lowered quality of life are causative for the emergence of many social problems (alcoholism, drug addiction, suicides, and crimes). Leisure activities like watching television, playing computer games and similar free time actions are supposed to be problematic for disabled patients as they are connected with psychological stress, hypokinesia (diminished motor function), hypodynamia (decreased muscular strength); nevertheless, such activities are most often suggested to them.

Communication. Vision, hearing, attention and comprehension are often impaired in patients. Therefore, it should be accounted for while communicating with such patients. In cases of written information sufficient illumination and size of letters are necessary, whereas when verbal information is given, accessory vocal interference is to be eliminated by turning down a radio, television, avoiding conversations at the same time with other people etc. Elderly people often do not comprehend information communicated to them, but they try not to disclose that fact. This is why $50 \%$ of the elderly take drugs improperly. 
Transportation system services. It is very important that transport, especially the public one, is to be adjusted to the needs of the individuals with impaired mobility and coordination, (low boarding, holders, and the like), blind people.

Social care and social service. Human existence is a social process. It is understood as a constant interaction with other individuals. Sick people often find it difficult to express their wishes, as physical and intellectual problems hinder them from imagining or recognizing their possibilities. Therefore, it is important to estimate special needs of daily and personal life, training, working activity and public life for the patients and provide adequate assistance for them.

Lost income compensation. This is a very important part of the rehabilitation system as it helps the person to establish a stable self-esteem. With financial situation secured, a person becomes "The captain of his/her own ship". Financial support must be assigned to warrant personal material conditions (social allowance, compensation for accommodation, heating, hot and cold water supply and so on), nursing, care and aid, transportation and other expenses.

Training of specialists. Proper adjustment of versatile rehabilitation means performed by specialists working in this field demands not only thorough knowledge of biomedical sciences, but also the educational issues, psychology, sociology and practical skills necessary for working with the disabled.

Interdisciplinary team training develops collaboration, reduces staff burnout, and improves rehabilitation implementation, and increases client participation and satisfaction.

All rehabilitation specialists should know that:

1) human is a bio-psycho-social being

2) an individual exists in a certain environment (family, community, country et cetera);

3) consequences of a disease are:

- biological (unpleasant feelings: pain, incapacity, dyspnoea, urinary incontinence and other),

- psychological (stress, depression, agitation),

- social (disturbed activity and function, changed social role and connections, decreased hopes of future );

4) there are various treatment and rehabilitation methods and means;

In Lithuania, physical medicine and rehabilitation doctors, social workers, physiotherapists, speech therapists, occupational therapists, orthotists, public health specialists (bachelors, masters) are adequately trained to work with the disabled. We have to admit with regret, however, that the number of these specialists is several times lower than in the older European countries.

Medical social expertise (Working capability and disability assessment). In disability assessment of severe patients, it is of high importance that the focus of 
attention is to be put not on what they are not capable of doing, but rather what they are capable of doing, to avoid stigmatization and enhance the individual self-value.

Economic benefits of rehabilitation system are:

- seriously ill patients' hospitalization period shortens,

- severe disease complications (bedsores, contractures, thromboembolism etc.) are avoided,

- number of used drugs decreases,

- psychological climate in the family improves,

- the extent of necessary nursing decreases,

- some of the rehabilitees return to working activities,

- patient's independence and quality of life increase,

- length of life is extended,

- exacerbations of the disease and frequency of repeated hospitalizations decrease.

It has been calculated that one currency unit put into the rehabilitation system pays dividends nine fold.

Research in rehabilitation. Lack of reliable research hinders the development and implementation of effective rehabilitation policies and programs. More research on rehabilitation in different contexts is needed. Better data are needed on service provision, service outcomes, and the economic benefits of rehabilitation.

\section{CONCLUSION}

Rehabilitation of the disabled, their social integration, improvement of the quality of their life in every country is rather a complicated problem in various aspects: legal, medical, economical, and even moral. Establishment of the complex rehabilitation system for the disabled is a great challenge. Coordination of multidisciplinary rehabilitation is required to ensure the continuity of care. The aim of coordinated rehabilitation is to improve functional outcomes and reduce costs. Evidence has shown that the provision of coordinated, multidisciplinary rehabilitation services can be effective and efficient. Multidisciplinary teams can convey many rehabilitation benefits to patients. International cooperation can help share good and promising practices and provide technical assistance to countries that are introducing and expanding rehabilitation services.

\section{REFERENCES}

Chamberlain, M. A. (2015). Supporting rehabilitation in developing countries. Journal of Rehabilitation Medicine, 47(8), 673-674.

Kriščiūnas, A., Kowalski, I. M. (2010). Ensuring rehabilitation and a full quality of life for patients with chronic non-infectious diseases. Polish Annual Medicine, 17 (1), 112-122. 
Kriščiūnas, A. (2015). Negalia ir požiūris ị ją šiuolaikinèje visumenèje. Sveikatos mokslai, 25, 4-15.

WHO Global Disability Action Plan 2014-2021. Internet link: http://www.who.int/disabilities/action plan/en/.

WHO, (2007). International Classification of Functioning, Disability and Health (Children and Youth version). Geneva: World Health Organization.

WHO. (2001). International Classification of Functioning, Disability and Health. Geneva: World Health Organization.

WHO. (2008). The Global Burden of Disease: 2004 Update. Geneva: World Health Organization.

WHO. (2011). World Report on Disability. Geneva: World Health Organization.

\section{NEĮGALIŲJŲ REABILITACIJOS PARADIGMA}

Aleksandras Kriščiūnas

Lietuvos sporto universitetas

\section{SANTRAUKA}

Tyrimo pagrindimas. Negalia yra būklè, kai žmogus dẻl sveikatos sutrikimų negali pasirūpinti asmeniniu ir socialiniu gyvenimu. Kiekvienoje šalyje ir epochoje susiduriama su daugybe problemų sprendžiant neigaliųų socialinès integracijos klausimus. Ši problema globali ir darosi vis aktualesnè dèl visuomenès demografinių pokyčių, jos senėjimo. Neịgaliujų skaičius auga dèl lètinių neinfekcinių ligų: širdies kraujagyslių, cukrinio diabeto, psichikos sutrikimų ir kt. gausèjimo.

Tikslas - pateikti šiuolaikinị požiūrị ị neịgaliųjų reabilitaciją ir jų reabilitacijos sistemos kūrimą.

Aptarimas. Neigaliujų reabilitacijos sistemos sukūrimas yra didelis iššūkis. Sistemos kūrimui būtinos plačios apimties teisinès, medicininès, ekonominès, organizacinès ir kitos priemonès, kurios padeda atkurti neigaliųų sutrikusias biopsichosocialines funkcijas ir adaptuotis visuomeneje. Straipsnyje pateikiami duomenys apie neigaliujų reabilitacijos sistemos sudètines dalis, neigaliujų funkcinès būklès ir jų poreikių vertinimą taikant „Tarptautinę funkcionavimo, neigalumo ir sveikatos klasifikaciją“ bei jų tenkinimą, įskaitant kompensacines technines priemones.

Išvada. Daugelio specialistų komandos gali užtikrinti reabilitacijos naudą pacientams. Tarptautinis bendradarbiavimas gali padèti keistis geraja praktika ir siūlo techninę pagalbą šalims, teikiančioms ir plečiančioms reabilitacijos paslaugas.

Raktažodžiai: reabilitacija, neigalieji, biopsichosocialinès funkcijos, TLK. 